Journal of Contemporary Educational Research

Research Article

\title{
Discuss the Role, the Purpose and the Rhythm of Education
}

Mingting $\mathrm{Fu}^{*}$, Huamei Wang

Normal College, Qingdao University, Qingdao 266071, Shandong Province, China

\begin{abstract}
Although education can promote individual development, education only works to the extent that it can be shaped. The purpose of education is not only to instill knowledge, but also to teach children to see the essence through phenomena. Education is the art of teaching people how to use knowledge. In education, teachters should grasp the rhythm of education and make education an art.
\end{abstract}

Key words: Purpose of education; The imparting of knowledge; Art; The rhythm of education

Publication date: October, 2020

Publication online: 31 October, 2020

*Corresponding author: Mingting Fu,995735094@ qq.com

\section{Introduction}

Education can promote individual development, but there is such a phenomenon in life. Whether ancient or modern education, the concept of educational hierarchy always exists. Confucius put forward the idea of wisdom above and folly below. Furthermore, perspectives of poor people who find it difficult to achieve results are also popular. These phenomena seem to question the idea that what can education change? What is the purpose of education?

2 The role of education is to develop the uniqueness of the individual and maximize its potential

Many parents say," don't let your child lose at the starting line". The starting line that people most often mention is actually the starting point of life. Such as heredity, material resources and the cultural atmosphere of the family are the innate conditions of a child. A person from birth, its starting point is fixed, each child seems to have a different starting line, the starting line between different children may be far away. If you think education is useful, even if the starting line between the two children is very different, through education and training, the gap between them will be smaller and smaller, and the last two will become very good. But if you take another view, even if two children receive the same education and intentional training, there is still a big gap between them, basically consistent with the original level, these children can only be in the original class, then it means that you are invisibly denying the role of education. So what can education change? Karl Jaspers says there are three kinds of resistance to selfgeneration: intrinsic immutability, intrinsic plasticity, and original self-existence, while education only plays a role in intrinsic plasticity ${ }^{[1]}$. In this way, education works, but it works only to the extent that it can be shaped. The book also mentions that "education can only promote the development of people's education according to their talents and possibilities, and education can not change the nature of life" ${ }^{\text {"[1] }}$. Therefore, people have a premise before receiving education, human nature is different, can not be changed, never expect everyone to become an insightful thinker. What education can change is to develop the possibility of human beings, so that children's talents can develop better. The function of education is to choose the perfect educational content, let the children choose freely in practice, and make themselves what kind of person. In other words, the role of education is to develop the uniqueness of the individual and maximize its potential.

But in education, we often do things that seem 
useless. Is the purpose of education only to impart knowledge? On the one hand, education should train people with both culture and expertise. On the other hand, education is an art that teaches people how to use knowledge ${ }^{[2]}$. This is a seemingly concrete and general view, since education has to do something boring, what is this art?

Let's give an example. What is the meaning of solving the quadratic equation? Why teach children to solve the quadratic equation? The traditional answer to this question is that the brain is a tool, you first have to make the brain sharp, and then use it to master the process of solving the quadratic equation is a process of sharpening the brain. In traditional ideas, this is a process of indoctrination in education to teach you this knowledge of mathematics, whether you understand it or not. Alfred North Whitehead once said that the human brain is not passive. Why do we learn the quadratic equation? The quadratic equation is a part of algebra, and algebra is a way to quantify the world, which is an example to guide us to explore the world. So the problem that education needs to solve is to let students learn the whole knowledge by learning some knowledge. Reflecting on our present mathematics teaching, this kind of education through a small part does not seem to get a good interpretation. Teachers seem to teach knowledge for knowledge points, and students learn only to learn a certain knowledge point. So teachers' teaching of concepts seems to have far exceeded the study of principles and methods. Children only use the brain as a tool to sharpen it. From this phenomenon, we can see that this teaching model seems to be contrary to our ideal education. Alfred North Whitehead also put forward two precepts, one is not to teach too many subjects, the other is that the subjects taught must be thorough, and I think it is very practical. Knowledge is not as much as possible. The most important thing is to enable students to understand what they have learned, to see the essence through phenomena, and to see the woods through trees. Therefore education should teach children how to use knowledge, not just knowledge itself. The significance of learning knowledge lies in the ability to freely apply these knowledge, actively master these knowledge, can not let knowledge in turn control human nature. This is a very important point. The process of education not only involves the processing of knowledge, the choice and application of knowledge, but also makes our intuitive experience more valuable. This statement also verifies the initial view of educational purpose, education is the art of teaching people how to use knowledge.

\section{Grasp the rhythm of education}

If education is called an art, we should grasp the rhythm of education in the process of education. Alfred North Whitehead once mentioned three stages of intellectual development, romantic stage, precise stage and comprehensive application stage ${ }^{[2]}$. In fact, these three stages of intellectual development can also show a process of people acquiring knowledge. First, the romantic stage is the first stage of understanding knowledge, when we are in the stage of direct understanding of facts, but occasionally make a systematic analysis of facts, from contact with simple facts, To begin to understand the importance of unexplored relationships between facts. Second, the precision stage is the stage of increasing and supplementing knowledge, in which the extensive relationship of knowledge is secondary to the accuracy of systematic elaboration, and we obtain other facts in a structured order, thus explaining and analyzing the general content of the romantic stage. In the end, comprehensive application stage, equivalent to a result of education, is the goal of precision training. In this way, education should be a process of repeated cycles. The rhythm of education is closely related to the view that education is "an art that teaches people how to use knowledge ", and the process of using knowledge corresponds to the stage of comprehensive application. The above mentioned three stages not only correspond to the stages of intellectual development in life, but also are made up of repeated cycles in each small experience of life. For example, every lesson in our life, every subject, every stage of life is composed of these three stages, and has been running around. In the above three stages, their corresponding characteristic is the triple cycle of freedom, discipline and freedom. The purpose of education should be to make self-discipline a spontaneous result of free choice, while freedom should be given rich opportunities because of discipline. Therefore, in our education, we should also learn the rhythm of this education, no matter at any stage should coordinate the relationship between freedom and discipline.

Any activity that can enhance people's knowledge and skills and affect people's moral character can be called education. Education is neither the process of indoctrination nor the process of loading items into suitcases. Education has its own characteristics, and 
the process of education is a process of active choice. Most similar to this process is the process of biological absorption of food, if the child is fed inappropriate food, it will not accept the absorption, biological organisms have the opportunity to choose. On the whole, education is to prepare people for all kinds of direct experiences and experiences in life, to have relevant ideas and appropriate actions to cope with the situation that occurs all the time. The whole purpose of education is to give people active wisdom. The process of education should be an active process, a process for the educated to explore, understand and practice actively, and this process should be an art.

Let's look back at the issues mentioned earlier. What is the role of education? What is the purpose of education? What do we need to pay attention to in education? We can conclude that although education can promote individual development, education only works to the extent that it can be shaped. So we can inspire children by educating them. The purpose of education is not only to instill knowledge, but also to teach children to see the essence through phenomena. Education is the art of teaching people how to use knowledge. In education, teachers should grasp the rhythm of education and make education an art.

\section{References}

[1] Karl J, Zou J. What is Education[M]. Beijing: life Reading Xinzhi Sanlian Bookstore, 1991.

[2] Alfred NW, Xu RZ. Purpose of education[M]. Beijing: life Reading Xinzhi Sanlian Bookstore, 2002. 